\title{
Effect of Different Temperature-Controlled Ultrasound on the Physical and Functional Properties of Micellar Casein Concentrate
}

\author{
Bong Song, Yumeng Zhang, Baojia Yang, Panpan Zhu, Xiaoyang Pang $\mathbb{D}$, Ning Xie, Shuwen Zhang * and Jiaping Lv \\ Institute of Food Science and Technology, Chinese Academy of Agricultural Sciences, Beijing 100193, China; \\ 82101192170@caas.cn (B.S.); 82101191117@caas.cn (Y.Z.); 82101205366@caas.cn (B.Y.); 82101195218@caas.cn (P.Z.); \\ pangxiaoyang@caas.cn (X.P.); xiening@caas.cn (N.X.); lvjiaping@caas.cn (J.L.) \\ * Correspondence: zhangshuwen@caas.cn; Tel.: +86-010-6281-5542
}

Citation: Song, B.; Zhang, Y.; Yang, B.; Zhu, P.; Pang, X.; Xie, N.; Zhang, S.; Lv, J. Effect of Different Temperature -Controlled Ultrasound on the Physical and Functional Properties of Micellar Casein Concentrate. Foods 2021, 10, 2673. https://doi.org/ $10.3390 /$ foods 10112673

Academic Editor: Golfo Moatsou

Received: 24 September 2021

Accepted: 29 October 2021

Published: 3 November 2021

Publisher's Note: MDPI stays neutral with regard to jurisdictional claims in published maps and institutional affiliations.

Copyright: (c) 2021 by the authors. Licensee MDPI, Basel, Switzerland. This article is an open access article distributed under the terms and conditions of the Creative Commons Attribution (CC BY) license (https:// creativecommons.org/licenses/by/ $4.0 /)$.

\begin{abstract}
Micellar casein concentrate (MCC) is a novel dairy ingredient with high protein content. However, its poor functional properties impair its potential for further application, highlighting the importance of using innovative processing methods to produce modified MCC, such as ultrasound (US). This work investigated the impact of US on the physical and functional properties of MCC under temperature-controlled and -uncontrolled conditions for different time intervals. Under temperaturecontrolled ultrasound (TC-US) treatment, a reduction was found in the supernatant particle size of casein micelles. Soluble calcium content and hydrophobicity increased following ultrasound treatment at $20^{\circ} \mathrm{C}$, resulting in a remarkable improvement in emulsification. However, long-time ultrasonication led to an unstable state, causing the MCC solutions to show shear thinning behavior (pseudoplastic fluid). Compared with $50{ }^{\circ} \mathrm{C}$ temperature-controlled ultrasonication, ultrasonication at $20^{\circ} \mathrm{C}$ had a greater influence on particle size, viscosity and hydrophobicity. These findings indicate that $20^{\circ} \mathrm{C}$ TC-US could be a promising technology for the modification of MCC.
\end{abstract}

Keywords: ultrasound; micellar casein concentrate; temperature-controlled; emulsification

\section{Introduction}

Ultrasound (US) is one of the rapidly developing innovative and green techniques that offer great potential for implementation in the food industry. Compared with other techniques (microwaves, gamma radiation), sound waves are generally considered safe, non-toxic, and environmentally friendly, making the use of ultrasound highly advantageous [1,2]. Compared with high-frequency ultrasound (20-100 kHz), low-frequency ultrasound $(2-10 \mathrm{kHz})$ has found application in a wide range of dairy research applications, such as inactivation of microorganisms, extraction of components from cells or tissues, acceleration enzymatic activity, and dissolution of large particles [3-6].

Milk, a rich source of nutrients, can be fractionated into a wide range of components for use in food and beverages [7,8]. Micellar casein concentrate (MCC) is a novel ingredient with high casein content and a minor amount of lactose and minerals that is manufactured by microfiltration (MF) of skim milk, and is commercially available as a liquid, concentrate, or dried powder containing $\geq 8, \geq 22$, and $\geq 80 \%$ total protein, respectively $[9,10]$. MCC is widely used in cheese and ice cream production. However, due to its relatively poor solubility and emulsification, a large content of emulsifying salt (ES) needs to be used to achieve uniformity. Excessive addition of ES always leads to a decrease in thermal stability and hardness, highlighting the need to produce modified MCC. The current research on the effects of US on MCC is mainly focused on the modification of redissolved MCC powder. Some studies have shown that ultrasound could improve its solubility and intestinal digestibility [11,12]. These ultrasound treatments have often been performed for short periods ( $<10 \mathrm{~min}$ ) without temperature control or for temperature controlled for long 
periods at low temperatures $\left(<10^{\circ} \mathrm{C}\right)$ on a laboratory scale. However, few studies have been published about the effect of US on MCC at different medium temperatures.

Medium temperature is also a key factor that can affect the generation of bubbles and the cavitation effect. More bubbles will be generated at higher temperatures because of the decrease in medium viscosity and tensile strength, further increasing the cavitation effect [13]. However, whey protein will be denatured if the temperature reaches above $65^{\circ} \mathrm{C}$. Hence, it is necessary to choose the appropriate medium temperature for US treatment. In this research, room temperature $\left(20^{\circ} \mathrm{C}\right)$ and medium-high temperature $\left(50^{\circ} \mathrm{C}\right)$ were chosen. The objective was to examine the effect of ultrasound under uncontrolled and controlled temperature on the physical and functional properties of MCC solutions, with a focus on the changes of particle size, viscosity, emulsifying activity index and fluid behavior.

\section{Materials and Methods}

\subsection{Materials}

Raw cow's milk was obtained from Sanyuan First Farm (Beijing, China) and separated at $63^{\circ} \mathrm{C}$ to remove fat (FT15-A, Armfield Limited, Ringwood, UK). Then, the skim milk was pasteurized in a plate heater at $72{ }^{\circ} \mathrm{C}$ for $15 \mathrm{~s}$ [14]. After pasteurization, the micellar casein concentrate was obtained according to our previous work $[15,16]$ by using a 3 -stage pilot-scale microfiltration system equipped with ceramic membrane with an average pore size of $100 \mathrm{~nm}$ (DONG QIANG MEMBRANE, Zibo, China). During the whole process, the concentration factor of the retentate was 3 and the transmembrane pressure was controlled at $0.5 \mathrm{MPa}$. Finally, the micellar casein concentrate contained $7.52 \%(w / w)$ casein, $0.92 \%(w / w)$ serum protein, $0.44 \%(w / w)$ lactose, and $0.29 \%(w / w)$ fat.

\subsection{Pilot-Scale Ultrasound System}

The experimental scheme used is depicted in Figure 1. Micellar casein concentrate was sonicated in a $7.5 \mathrm{~L}$ metal tank equipped with a heat exchanger and cooling water jacket, using a $20 \mathrm{kHz}, 4000 \mathrm{~W}$ ultrasonic horn (70 mm diameter, Hongxianglong Biotec, HXL-4000, Beijing, China) at an amplitude of 50\% for 5, 10, 15, 30 and $60 \mathrm{~min}$. The power output was determined to be $453 \mathrm{~W}$ by calorimetry and the energy density was calculated using the Eq as follows [17]:

$$
\text { Energy density }=(\mathrm{P} \times \mathrm{t}) / \mathrm{v}
$$

where $\mathrm{P}$ represents the output power $(\mathrm{W})$, $\mathrm{t}$ is the time (s), and $\mathrm{v}$ the volume of samples $(\mathrm{mL})$. On the basis of the calculation, the energy densities at 5, 10, 15, 30 and $60 \mathrm{~min}$ of residence time were 18, 36, 54, 108 and $216 \mathrm{~J} / \mathrm{mL}$, respectively. For the temperaturecontrolled group, the MCC solution temperature during US treatment was maintained at $20 \pm 2{ }^{\circ} \mathrm{C}$ and $50 \pm 2{ }^{\circ} \mathrm{C}$, respectively.

\subsection{Average Particle Size}

The MCC solution was divided into two parts; one part was used to measure the overall average particle size, the other part was centrifuged at $4000 \times g$ for $15 \mathrm{~min}$ and the upper liquid was taken to measure the particle size. A Malvern Master Sizer 3000 (Malvern Instruments, Worcester, UK) was used to measure the particle size with the refractive index of 1.58 at $25^{\circ} \mathrm{C}$ [12]. Five measurements were obtained for each sample.

\subsection{Zeta Potential Measurements}

Zeta potential measurements were obtained using the Zetasizer (Nano series, Malvern Instruments, Worcester, UK) at $25^{\circ} \mathrm{C}$ according to the method described by Nazari et al. [18]. 


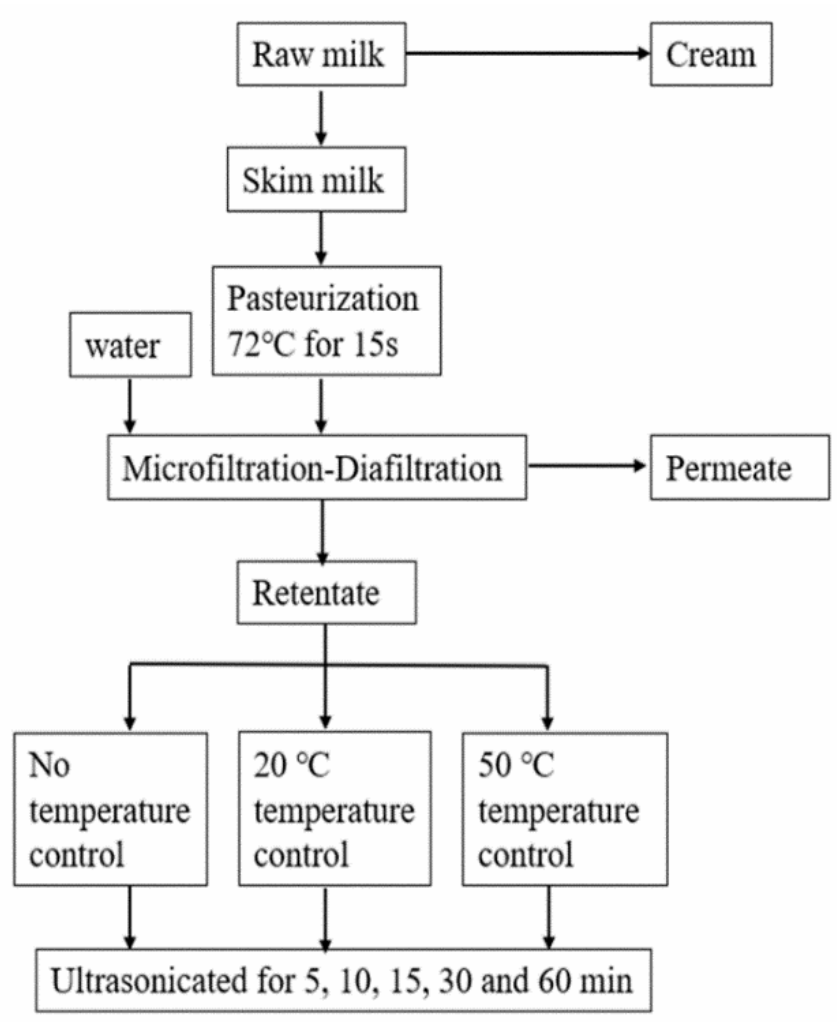

Figure 1. MCC production. After ultrafiltration and diafiltration, the retentates were treated for different US time and temperature.

\section{5. $\mathrm{pH}$ and Viscosity Measurement}

The $\mathrm{pH}$ of the untreated and US-treated solutions was measured using a $\mathrm{pH}$ meter (lab cHem, Australia) at $25{ }^{\circ} \mathrm{C}$. Viscosity of the MCC solutions were measured using a Rheometer cylinder (Physica MCR 502, Anton Paar Company, Melbourne, Austria) operated using Rheoplus software. Measurements were taken using a $25 \mathrm{~mm}$ measuring plate at $25{ }^{\circ} \mathrm{C}$ between the shear rates of 0.1 and $200 \mathrm{~s}^{-1}$ for $40 \mathrm{~min}$. Shear (apparent) viscosity was recorded as a function of shear rate and fitted according to the power-law equation: $\tau=K \gamma^{n}$ [19], where $\tau$ is the sheer stress, $\gamma$ is the sheer rate, $K$ and $n$ represent the consistency index $\left(\mathrm{N} \mathrm{s}^{\mathrm{n}} / \mathrm{m}^{2}\right)$ and flow behavior index, respectively.

\subsection{Soluble Ca Measurement and SDS-PAGE}

Aliquots $(10 \mathrm{~mL})$ of the untreated, ultrasonic-treated MCC samples were transferred into centrifuge tubes, then ultracentrifuged at $90,000 \times g$ for $2 \mathrm{~h}$ using a P40ST rotor in a L-80XP Ultracentrifuge (Hitachi WX, Tokyo, Japan), and the supernatants were carefully pipetted. The soluble $\mathrm{Ca}$ and overall $\mathrm{Ca}$ content were determined with an inductively coupled plasma mass spectrophotometer (Agilent, Santa Clara, CA, USA) according to the method described by Nassar et al. [20]. The content of micellar calcium was the difference between total calcium and soluble calcium content. SDS-PAGE was performed using a $4 \%$ stacking gel and a $12 \%$ resolving gel on Mini-Protein Tetra System (Bio-Rad Company, Oakland, CA, USA) and gel documentation system (Clinx Science Instruments Co, Ltd., Shanghai, China) according to the method of Yanjun et al. [21].

\subsection{Emulsion Activity Index (EAI) and Emulsion Stability (ES)}

The emulsion activity index (EAI) and emulsion stability (ESI) were measured by the absorbance at $500 \mathrm{~nm}$ using a spectrophotometer (Gipp, UV-1900PCS, Shanghai, China) according to the method described by Zhang, Pang, Lu, Liu, Zhang and Lv [11]. However, the preparation for the emulsion was modified as follows: ten-milliliter portions of MCC solution were diluted to $40 \%(w / w)$ with ultrapure water; then, the commercial soybean 
oil was added at the ratio of 1:3 and mixed. A rotary homogenizer set for $1.5 \mathrm{~min}$ at $9000 \mathrm{rpm}$ (T25, IKA Inc., Staufen, Germany) was used for the preparation of emulsions. The emulsifying activity index (EAI) and emulsion stability (ESI) were calculated as follows [22]:

$$
\begin{gathered}
\mathrm{EAI}=\left(2 \times 2.303 \times \mathrm{D} \times \mathrm{A}_{0}\right) /(10000 \times \mathrm{C} \times \theta) \\
\mathrm{ES}=\mathrm{A}_{0} /\left(\mathrm{A}_{0}-\mathrm{A}_{20}\right)
\end{gathered}
$$

where $\mathrm{D}$ is the dilution ratio, $\mathrm{A}_{0}$ is the absorbance of emulsion at $0 \mathrm{~min}, \mathrm{~A}_{20}$ is the absorbance of emulsion formed after $20 \mathrm{~min}, \mathrm{c}$ is the protein concentration, and $\theta$ is the volume concentration of soybean oil.

\subsection{Surface Hydrophobicity and Intrinsic Fluorescence Spectroscopy}

Hydrophobicity and intrinsic fluorescence spectroscopy of the MCC solutions were measured as described by Zhong and Xiong [23], with some modifications. A series of protein concentrations $(0.005-0.25 \%)(w / v)$ from each MCC solution were prepared using $10 \mathrm{mM}$ phosphate buffer at $\mathrm{pH}$ 7.2. Then, $30 \mu \mathrm{L}$ of ANS-NA (sodium-8-anilino-1naphthalene sulfonate) was added to $4 \mathrm{~mL}$ of diluted samples and mixed. The relative fluorescence intensity (RFI) of the protein solutions was measured using a fluorescence spectrometer (F-2500, Hitachi, Ltd., Tokyo, Japan) at excitation and emission wavelengths of $390 \mathrm{~nm}$ and $470 \mathrm{~nm}$. The hydrophobicity value was determined by a scatter plot of net RFI with protein concentration. For fluorescence spectroscopy, MCC samples were diluted to $0.05 \mathrm{mg} / \mathrm{mL}$ solutions. The excitation wavelength was set at $280 \mathrm{~nm}$ and the emission spectra were measured from 300 to $450 \mathrm{~nm}$ at a scanning speed of $1500 \mathrm{~nm} / \mathrm{min}$ [24].

\subsection{Statistical Treatment}

All data are expressed as mean \pm standard deviation (SD) from at least three independent trials. Statistical analysis of the experimental data was performed by analysis of variance (ANOVA), and the significance of the difference between means was determined by Duncan's multiple range test $(p<0.05)$.

\section{Results and Discussion}

\subsection{Average Particle Size}

Figure 2a shows the overall average particle size of US-treated and untreated MCC samples as a function of US time under controlled $\left(20^{\circ} \mathrm{C}, 50{ }^{\circ} \mathrm{C}\right)$ or uncontrolled temperature conditions. The size of the soluble particles exhibited a slight decreasing trend from $0 \mathrm{~min}$ up to $30 \mathrm{~min}$ (energy density: $108 \mathrm{~J} / \mathrm{mL}$ ) under controlled temperature conditions. This result was in agreement with Shanmugam et al. [25], who reported $20 \mathrm{kHz}$ ultrasound at $41 \mathrm{~W}$ could slightly reduce the particle size of pasteurized homogenized skim milk [26]. In our experiment, a maximum reduction in size occurred during the first 15 min (energy density: $54 \mathrm{~J} / \mathrm{mL}$ ) under uncontrolled temperature (about $15 \mathrm{~nm}$ smaller than initial solution), but US for longer than $30 \mathrm{~min}$ resulted in a large and progressive increase in the particle size. This phenomenon might be related to the denatured serum protein aggregation caused by high temperature in long ultrasonic time [27]. Under US treatment without temperature control, the temperature of the samples would achieve over $80^{\circ} \mathrm{C}$, resulting in denaturation of serum proteins. On this occasion, the levels of $\beta$ lactoglobulin and $\alpha$-lactalbumin in serum phase decreased with prolonged US time, while the levels of $k$-casein increased [25]. These newly formed denatured/aggregated soluble whey proteins would interact with $\mathrm{k}$-caseins present on the surface of the casein micelles or form aggregates in the serum phase, further exhibiting an increase in particle size. 


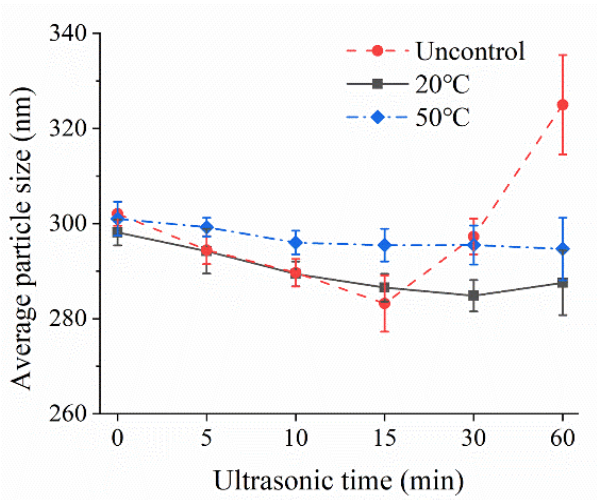

a

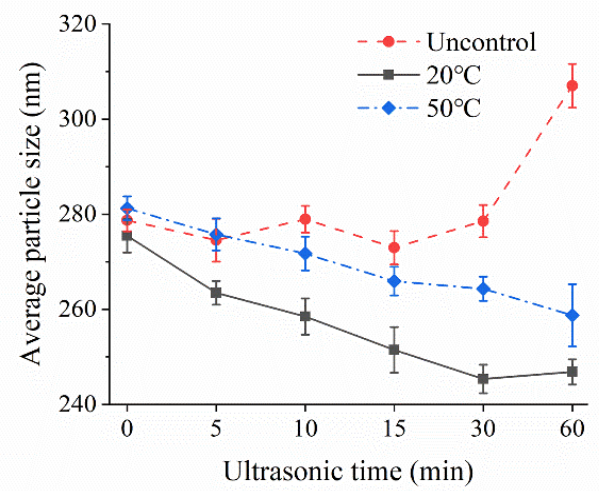

b

Figure 2. Overall average particle size (a) and supernatant average particle size (b) under uncontrolled, $20^{\circ} \mathrm{C}$ and $50^{\circ} \mathrm{C}$ temperature-controlled ultrasonication for different time intervals $(n=3$ or 4$)$ : uncontrol $(\bullet), 20^{\circ} \mathrm{C}$ temperature control

), $50{ }^{\circ} \mathrm{C}$ temperature control $(\diamond)$.

When the MCC were centrifuged at $4000 \times g$ for $15 \mathrm{~min}$, large micellar casein would be sedimented while native serum proteins, small micellar caseins, free caseins and serum protein aggregates still existed in the supernatant. Figure $2 \mathrm{~b}$ showed the average particle size of MCC supernatants soluble particles as a function of sonication time under controlled or uncontrolled temperature. Except for uncontrolled temperature US treated MCC samples, the supernatant average particle size exhibited a significant $(p<0.05)$ downward trend with prolonged US time at $20^{\circ} \mathrm{C}$ and $50{ }^{\circ} \mathrm{C}$ so that the size was roughly $20 \mathrm{~nm}$ and $40 \mathrm{~nm}$ smaller than the initial size. The decrease of the supernatant particle size could be due to the breakup of aggregated whey protein, whey protein associated with $\mathrm{CN}$ micelles that may have formed during pasteurization and small caseins which were dissociated from large micellar caseins. Furthermore, the decrease observed in the average particle size of supernatants under $20^{\circ} \mathrm{C}$ temperature-controlled treatment was significantly higher in comparison to the size of uncontrolled temperature and $50{ }^{\circ} \mathrm{C}$ temperature-controlled samples.

Apart from the dissociation of micelles, it was interesting to note that reaggregation of free caseins occurred during ultrasound treatment. After centrifuged at 90,000 $\times g$ for $2 \mathrm{~h}$, the supernatant was mainly composed of serum protein and free caseins. As could been seen in Figure 3, the bands of free $\alpha$-caseins and $\beta$-caseins present in soluble supernatant were lighter at 30 and $60 \mathrm{~min}$ under $20^{\circ} \mathrm{C}$ temperature-controlled US treatment, implying some free caseins were precipitated by centrifugation. A possible explanation for this observation may be due to the reaggregation of the caseins with casein micelles caused by hydrophobic interaction and sheer forces of acoustic cavitation. The turbulent conditions generated by the ultrasound treatment have also been shown to increase particle mobility and promote the formation of aggregates.

\section{2. $p H$ and Calcium Content}

The $\mathrm{pH}$ and soluble calcium content could be used to indicate the integrity of casein micelles [28].

Figure $4 \mathrm{a}, \mathrm{b}$ show the effect of sonication on the calcium distribution and solution $\mathrm{pH}$, respectively. Although $\mathrm{pH}$ value had a tendency to decrease from $0 \mathrm{~min}$ up to $30 \mathrm{~min}$ under $20^{\circ} \mathrm{C}$ and uncontrolled temperature samples, no significant difference was observed. Some researchers believed US could alter the $\mathrm{pH}$ of a solution because of the formation of small amounts of nitric acid, which were generated by oxygen and nitrogen reaction under heat zone from the cavitation effect [29]. However, some studies have indicated that ultrasound might disrupt the natural mineral equilibrium present in milk, further affecting the $\mathrm{pH}$ value [30]. As can be seen from Figure $4 b$, there was a significant increase $(p<0.05)$ in soluble calcium content in long time US treatment, especially at 30 and 60 min under $20^{\circ} \mathrm{C}$. The soluble calcium content rose from 320 to 384 ppm, indicating ultrasound changed the 
structure of micellar casein and caused the micellar calcium transferred to the serum phase. In addition, no significant difference was observed under $50^{\circ} \mathrm{C}$ temperature-controlled US treated samples. This phenomenon could be ascribed to the high vapor pressure at high temperatures, which impairs the bubble generation and weakens the cavitation effect. The effect of ultrasound on calcium balance may be related to pressure effect caused by cavitation. High pressure probably induces disruption of ionic interactions between caseins and inorganic constituents, with a resulting release of calcium from the micelles to the soluble phase, but the exact mechanism of micelle dissociation on US treatment remained unclear.

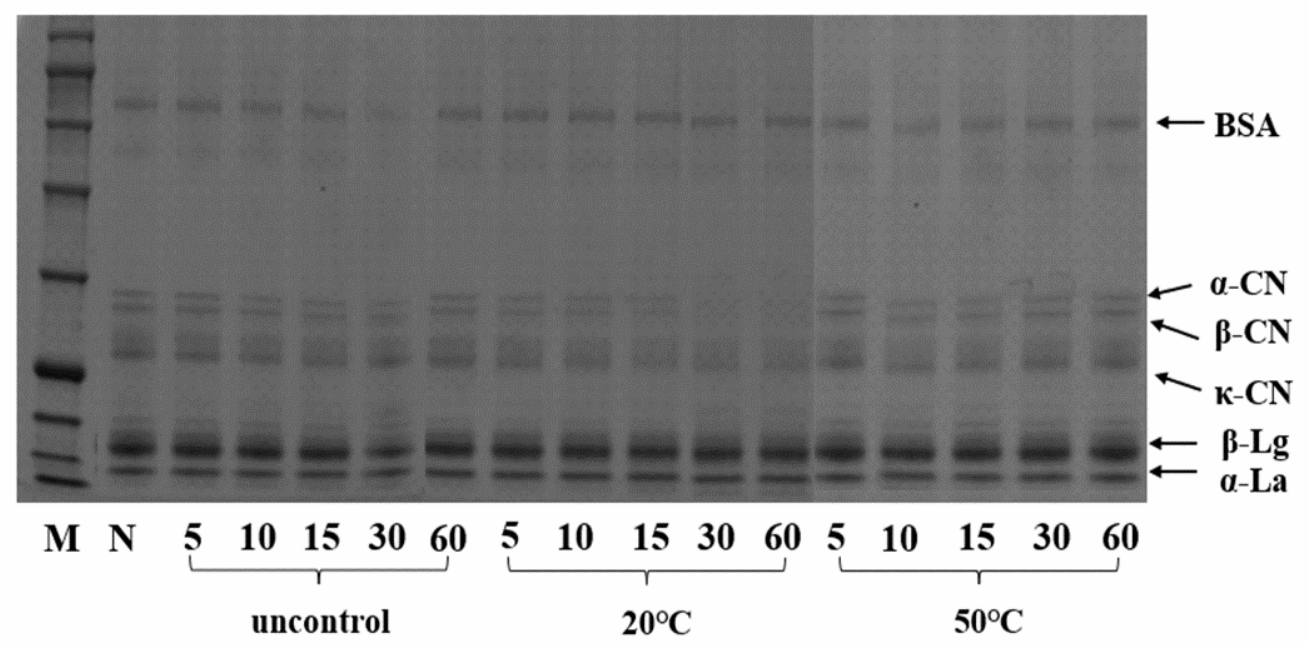

Figure 3. SDS-PAGE profiles of MCC supernatant (90,000 $\mathrm{g}$ for $2 \mathrm{~h}$ ) treated by US without temperature control or US combined with temperature control at different processing times $(5,10,15,30$ and $60 \mathrm{~min}$ ) and controlled temperatures $\left(20^{\circ} \mathrm{C}, 50^{\circ} \mathrm{C}\right)$. M: marker, $\mathrm{N}$ : native (untreated US) sample.

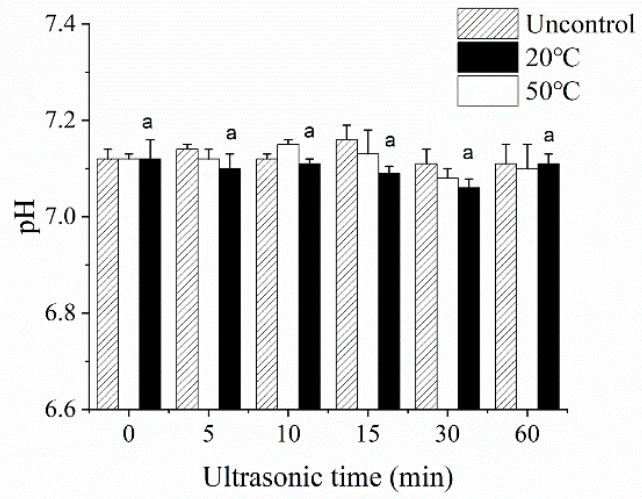

a

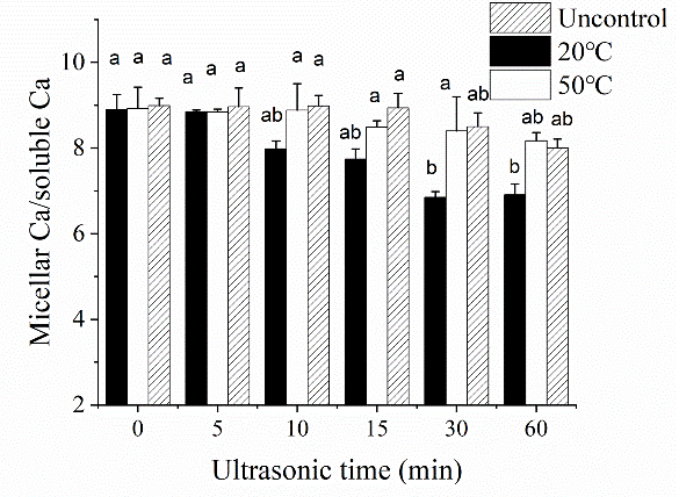

b

Figure 4. Mean $(n=4) \mathrm{pH}$ value (a) and the ratio of micellar Ca and soluble Ca (b) of MCC retentate under uncontrolled, $20{ }^{\circ} \mathrm{C}$ and $50{ }^{\circ} \mathrm{C}$ temperature-controlled ultrasonication for different time intervals. Means across all samples tested with different letters $(\mathrm{a}, \mathrm{b})$ differ significantly $(p<0.05)$.

In milk protein systems, the removal of calcium ions has often been accompanied by protein structural changes. As can be seen from Figure 5, the fluorescence intensity under $20{ }^{\circ} \mathrm{C}$ and $50{ }^{\circ} \mathrm{C}$ US treated samples is changed, indicating the quaternary structure of the casein was disrupted. Furthermore, US treatment always occurs concurrently with secondary structural rearrangements and partial unfolding into more intensive structure. Hong Bui et al. [31] applied second derivative infrared spectroscopy to analyze the influence of ultrasound on treated milk systems at different ratios of caseins and serum proteins, and found prolonged sonication resulted in the decreased $\alpha$-helix/large loop, and increased 
intermolecular $\beta$-sheet and random coil. This series structural and functional changes of MCC would heavily affect its application.
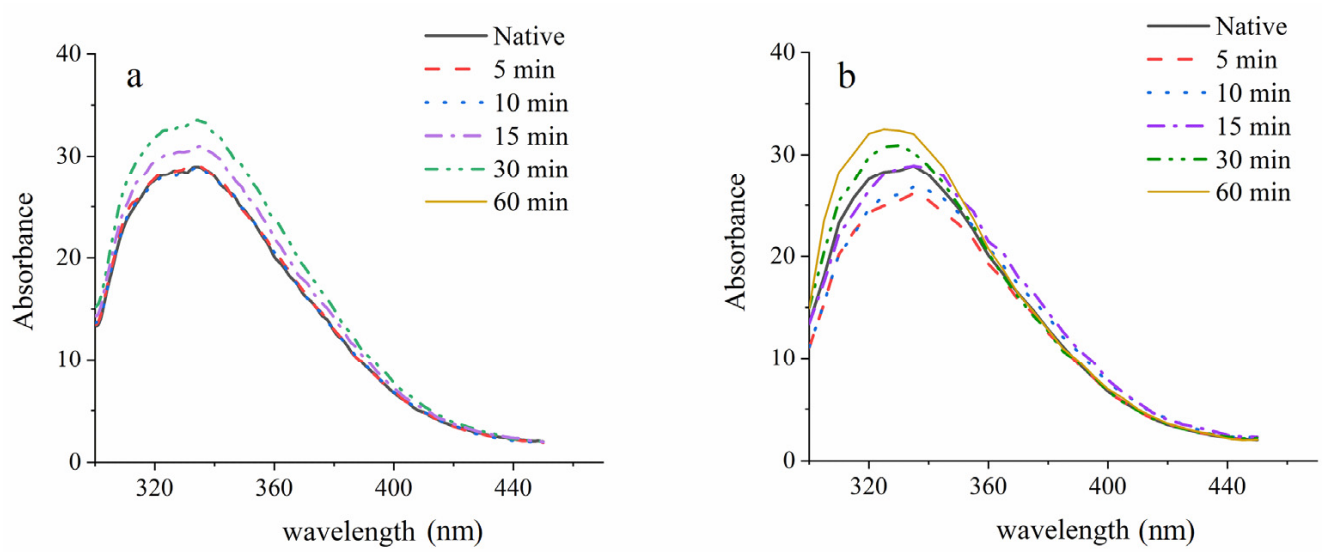

Figure 5. Fluorescence spectroscopy of micellar casein concentrate treated by ultrasound with $20^{\circ} \mathrm{C}$ (a) and $50{ }^{\circ} \mathrm{C}$ (b) temperature control.

\subsection{Rheological Properties}

The viscosity value for each MCC sample was recorded at the shear rate of $200 \mathrm{~s}^{-1}$, as presented in Figure 6.

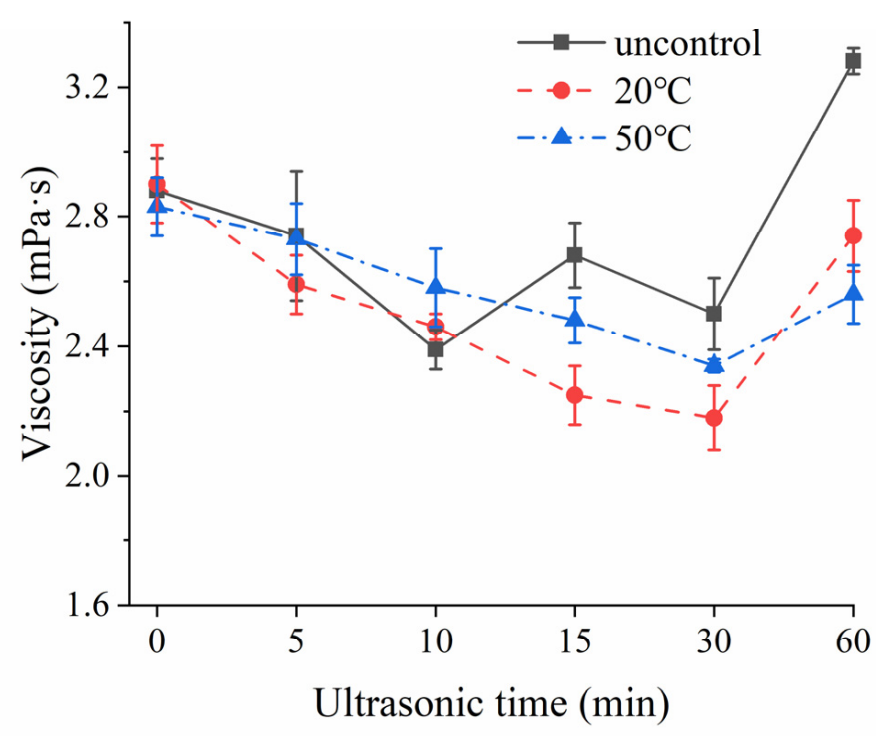

Figure 6. Mean $(n=4)$ viscosity of MCC samples at uncontrolled, $20{ }^{\circ} \mathrm{C}$ and $50{ }^{\circ} \mathrm{C}$ temperaturecontrolled ultrasonication for different time intervals: uncontrol $(\mathbf{\square}), 20^{\circ} \mathrm{C}$ temperature control $(\bullet)$, $50{ }^{\circ} \mathrm{C}$ temperature control (A).

Except for uncontrolled temperature US treated group, the viscosity of MCC samples displayed a decreasing trend with prolonged sonication time $(0-30 \mathrm{~min})$ at 20 and $50^{\circ} \mathrm{C}$. Moreover, $20^{\circ} \mathrm{C}$ temperature-controlled treatment showed a higher impact on viscosity reduction than that of observed at $50^{\circ} \mathrm{C}$. This result could be attributed to the particle size and zeta potential (Table 1). 
Table 1. Effect of ultrasound treatment at different temperatures and time intervals on zeta-potential of micellar casein concentrate.

\begin{tabular}{|c|c|c|c|c|}
\hline Temperature $\left({ }^{\circ} \mathrm{C}\right)$ & Time (min) & End Temperature ${ }^{1}\left({ }^{\circ} \mathrm{C}\right)$ & Energy Density (J/mL) & Zeta-Potential (mV) \\
\hline Native $^{2}$ & 0 & - & 0 & $-30.2 \pm-1.3^{a}$ \\
\hline \multirow[t]{5}{*}{ uncontrol } & 5 & 32 & 18 & $-28.1 \pm-1.1^{\mathrm{a}}$ \\
\hline & 10 & 39 & 36 & $-29.6 \pm-1.7^{\mathrm{a}}$ \\
\hline & 15 & 47 & 54 & $-28.9 \pm-1.2^{\mathrm{a}}$ \\
\hline & 30 & 62 & 108 & $-26.1 \pm-0.6^{\mathrm{ab}}$ \\
\hline & 60 & 84 & 216 & $-22.5 \pm-0.4^{c}$ \\
\hline \multirow[t]{5}{*}{$20^{\circ} \mathrm{C}$} & 5 & 20 & 18 & $-28.5 \pm-1.8^{a}$ \\
\hline & 10 & 21 & 36 & $-25.3 \pm-2.1^{\mathrm{ab}}$ \\
\hline & 15 & 20 & 54 & $-23.2 \pm-2.1^{b c}$ \\
\hline & 30 & 20 & 108 & $-21.4 \pm-1.3^{c}$ \\
\hline & 60 & 22 & 216 & $-21.2 \pm-0.8^{c}$ \\
\hline \multirow[t]{5}{*}{$50^{\circ} \mathrm{C}$} & 5 & 49 & 18 & $-28.8 \pm-0.7^{\mathrm{a}}$ \\
\hline & 10 & 50 & 36 & $-26.6 \pm-1.4^{b}$ \\
\hline & 15 & 51 & 54 & $-25.2 \pm-1.4^{\mathrm{ab}}$ \\
\hline & 30 & 52 & 108 & $-24.4 \pm-0.3^{b}$ \\
\hline & 60 & 52 & 216 & $-24.2 \pm-0.3^{b}$ \\
\hline
\end{tabular}

Values are means $(n=5)$; means in the same column not sharing a common superscript letter are significantly different $(p<0.05) .{ }^{1}$ End temperature: the temperature of MCC after US-treated. ${ }^{2}$ Native: none US treated mi cellar casein concentrate sample.

The average particle size of the supernatant decreased with US time under 20 and $50{ }^{\circ} \mathrm{C}$. Due to the decreased particles, the hydrodynamic diameter, molecular mobility and internal friction resistance was reduced, resulting in decreased viscosity. Similar results were obtained by the work of Deshpande and Walsh [32], who reported application of low-frequency ultrasound could reduce the viscosity of the reconstituted skim milk $(\mathrm{rSM})$ and reconstituted milk protein concentrate (rMPC). However, in the work of Lo et al. [33], they reported that the application of low-frequency ultrasound had no effect on the viscosity of the sodium caseinate suspensions. This difference was primarily due to the absence of large aggregates in reconstituted sodium caseinate suspensions. The overall effect of low-frequency sonication was largely insignificant when the casein proteins were not present in the micellar state.

When the MCC solution was ultrasonicated for $60 \mathrm{~min}$, the zeta potential value was significantly lower than that of other samples, implying that the whole solution system was not stable and stronger intermolecular forces were formed between the particles. This would reduce the molecular mobility and made it hard to deform under external forces applied by the rotor, hence exhibiting an increase in apparent viscosity. Meanwhile, this unstable system had a huge influence on the state of the fluid movement, as shown in Figure 7. Except for $60 \mathrm{~min}$ ultrasound treatment under uncontrolled and 20 temperaturecontrolled groups, both shear stress and shear rate changed linearly at all temperature levels. Shear rate and shear stress were fitted according to the power-law equation: $\tau=\mathrm{K} \gamma^{\mathrm{n}}$ [34]. On the base of this calculation, the flow behavior index value of most US treated and untreated MCC samples was around 1, exhibting Newton fluid behavior [35]. However, the flow behavior index under $60 \mathrm{~min}$ for uncontrolled temperature and for 20 controlled temperature was 0.82 and 0.79 , respectively, showing shear thinning behavior (pseudoplastic fluid). Thus, long-time ultrasound treatment could change the state of fluid movement. The formation of pseudoplastic fluid might be related to the entanglement networks caused by protein molecular chain [36]. There was less entanglement at high shear rates, while extensive entanglement at low shear rates [37]. 

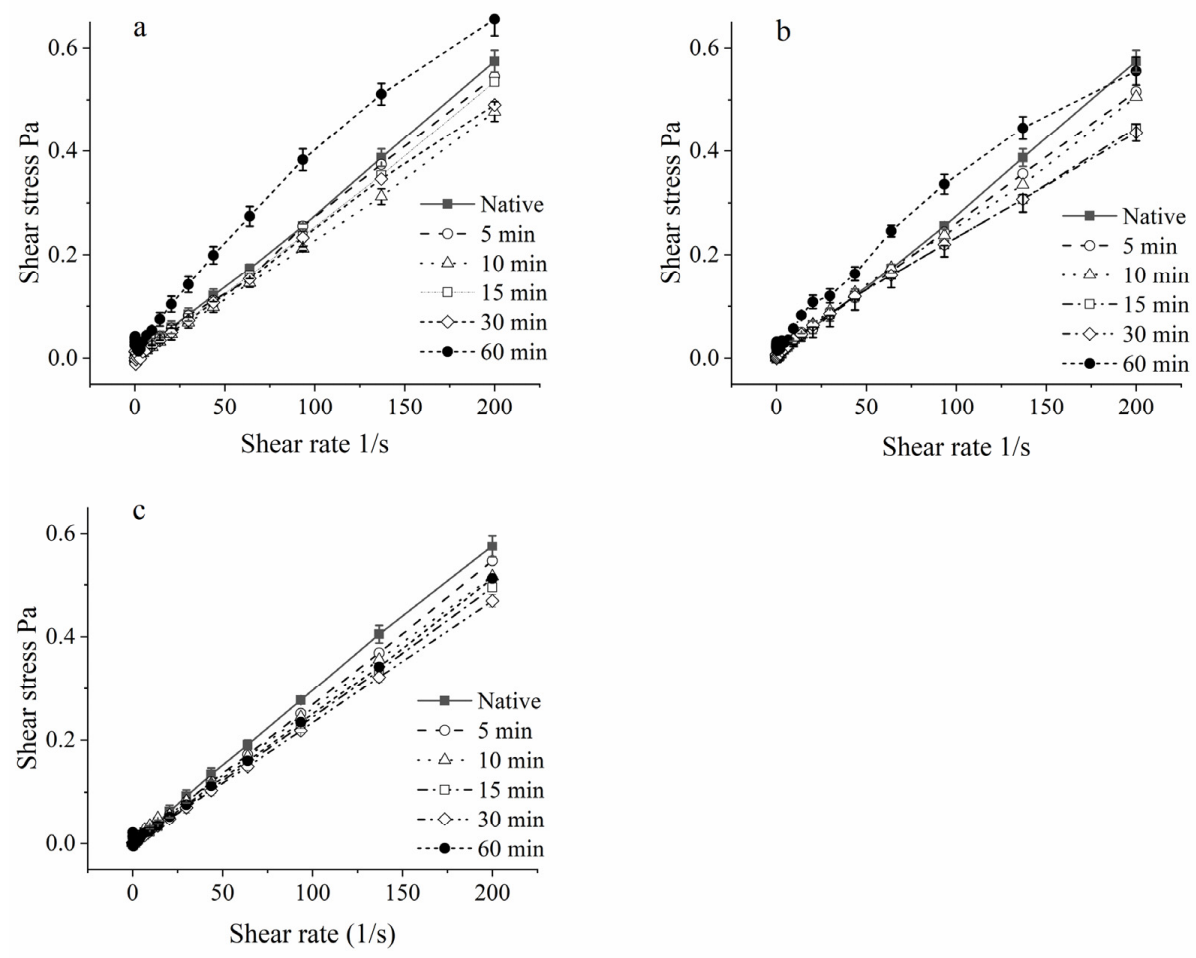

Figure 7. Mean $(n=3)$ viscosity of MCC samples at uncontrolled, $20^{\circ} \mathrm{C}$ and $50^{\circ} \mathrm{C}$ temperature-controlled ultrasonication for different time intervals: uncontrolled (a), $20^{\circ} \mathrm{C}$ temperature-controlled (b), $50{ }^{\circ} \mathrm{C}$ temperature control (c).

\subsection{The Emulsifying Activity Index (EAI) and Emulsion Stability (ESI)}

Table 2 shows a significant improvement in EAI of MCC solutions under 20 temperaturecontrolled US treatment, in which the maximum EAI and ES were observed at $42.3 \pm 1.9$ and $87.1 \pm 5.1 \%$, respectively.

Table 2. Effect of ultrasound treatment at different temperatures and time intervals on emulsion activity index (EAI) and emulsion stability (ES) of micellar casein concentrate solutions.

\begin{tabular}{|c|c|c|c|c|}
\hline Temperature $\left({ }^{\circ} \mathrm{C}\right)$ & Time (min) & $\begin{array}{l}\text { Energy Density } \\
(\mathrm{J} / \mathrm{mL})\end{array}$ & EAI (\%) & ES (\%) \\
\hline native & 0 & 0 & $28.6 \pm 0.7^{a}$ & $74.5 \pm 5.4^{b}$ \\
\hline \multirow[t]{5}{*}{ uncontrol } & 5 & 18 & $28.8 \pm 0.6^{\mathrm{a}}$ & $73.9 \pm 7.1^{b}$ \\
\hline & 10 & 36 & $30.9 \pm 0.8^{a b}$ & $65.6 \pm 4.6^{\mathrm{a}}$ \\
\hline & 15 & 54 & $34.3 \pm 1.3^{b}$ & $71.2 \pm 5.3^{b}$ \\
\hline & 30 & 108 & $37.1 \pm 2.4^{\mathrm{c}}$ & $66.2 \pm 2.1^{\mathrm{a}}$ \\
\hline & 60 & 216 & $33.9 \pm 2.0^{b}$ & $74.1 \pm 2.0^{b}$ \\
\hline \multirow[t]{5}{*}{$20{ }^{\circ} \mathrm{C}$} & 5 & 18 & $30.8 \pm 4.2^{\mathrm{ab}}$ & $75.0 \pm 4.5^{b}$ \\
\hline & 10 & 36 & $34.4 \pm 2.9^{b}$ & $82.2 \pm 7.6^{c}$ \\
\hline & 15 & 54 & $37.8 \pm 0.9^{c}$ & $86.7 \pm 6.8^{c}$ \\
\hline & 30 & 108 & $42.3 \pm 1.9^{c}$ & $87.1 \pm 5.1^{\mathrm{c}}$ \\
\hline & 60 & 216 & $42.4 \pm 2.5^{c}$ & $84.9 \pm 1.7^{c}$ \\
\hline \multirow[t]{5}{*}{$50{ }^{\circ} \mathrm{C}$} & 5 & 18 & $26.9 \pm 2.3^{a}$ & $78.6 \pm 2.9 \mathrm{bc}$ \\
\hline & 10 & 36 & $27.5 \pm 3.2^{\mathrm{a}}$ & $75.4 \pm 2.2^{b}$ \\
\hline & 15 & 54 & $28.5 \pm 1.2^{\mathrm{a}}$ & $77.2 \pm 1.9^{b c}$ \\
\hline & 30 & 108 & $28.8 \pm 1.9^{\mathrm{a}}$ & $76.8 \pm 3.6^{b}$ \\
\hline & 60 & 216 & $29.4 \pm 2.0^{\mathrm{a}}$ & $75.9 \pm 4.0^{b}$ \\
\hline
\end{tabular}

Values are means $(n=4)$; means in the same column not sharing a common superscript letter are significantly different $(p<0.05)$. Native: none US treated micellar casein concentrate sample. 
With increased US treated time from 0 to $15 \mathrm{~min}$ at $453 \mathrm{~W}$ output power at $20^{\circ} \mathrm{C}$, the EAI did not show significant changes, but an increase from 15 to $30 \mathrm{~min}$ led to significant improvement $(p<0.05)$ and a small decrease at $60 \mathrm{~min}$. This result could be explained by the rearrangements structure of MCC, which increased the exposed internal hydrophobic groups on the surface of the protein, thereby reducing the interfacial tension and making it easier to be absorbed on the oil-water interface. However, excessive hydrophobicity might induce hydrophobic aggregation between proteins, further reduced the emulsification. The result in Figure 8 was in agreement with the observations of $\mathrm{H}_{0}$. In addition to the exposure of internal hydrophobic group, some studies revealed that the distribution of hydrophobic groups on the oil-water interface might also affect the emulsification. Amino acid sequence alignment and hydrophilic analysis revealed proteins with a well balance between hydrophobic and hydrophilic amino acid groups had high interfacial activity. In contrast, a long hydrophilic or hydrophobic fragment could adversely influence protein interfacial activity [38,39].

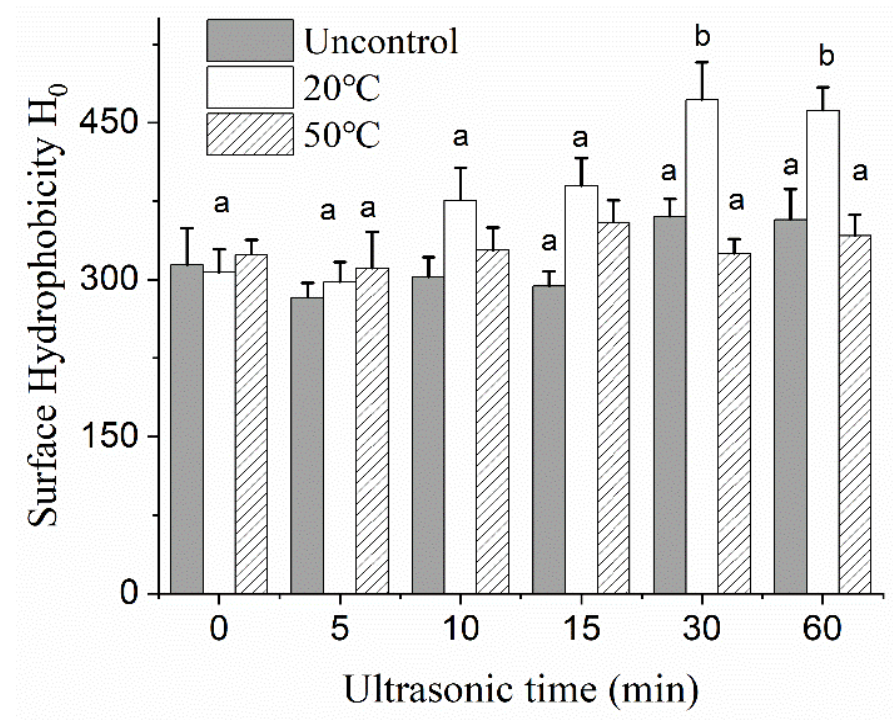

Figure 8. Surface hydrophobicity of MCC treated by ultrasonication without temperature control (dark column) and ultrasound combined with temperature control at different processing times (5, $10,15,30$ and $60 \mathrm{~min})$ and controlled temperatures $\left(20^{\circ} \mathrm{C}, 50^{\circ} \mathrm{C}\right)$. Means across all samples tested with different letters $(a, b)$ differ significantly $(p<0.05)$.

The EAI and $\mathrm{H}_{0}$ of the uncontrolled temperature group were observed to be slightly improved at 30 and $60 \mathrm{~min}$. These results could be explained by the dissociation of partial micellar calcium caused by thermal effect, which promoted structure slight changes and the stretch of protein molecules, causing it to wrap around small oil droplets. However, the emulsification index at $60 \mathrm{~min}$ was lower than that of $20{ }^{\circ} \mathrm{C}$ temperature-control group, which might be attributed to the presence of large particle aggregates. Because of the heat treatment, a large number of protein aggregates would be formed after protein denaturation, making it unable to effectively cover the entire fat droplet, resulting in emulsion instability.

It was interesting to note that no significant difference of EAI and surface hydrophobicity was observed at $50{ }^{\circ} \mathrm{C}$ US treatment. There were because of the high temperature of the system and the weakening of cavitation effect. Not only in terms of emulsification, but also with respect to particle size and viscosity, the effect of ultrasound at $50{ }^{\circ} \mathrm{C}$ seemed to be less significant than that of holding the temperature at $20{ }^{\circ} \mathrm{C}$. The temperature of the solution was a key factor for the ultrasonic intensity. On the one hand, increasing the temperature during the ultrasonic process could reduce the energy threshold for generating cavitation bubbles, and the bursting of more cavitation bubbles generated more uniform and stronger shear force [40]. On the other hand, as the processing temperature further 
increased, the vapor pressure inside the cavitation bubbles would gradually increase and produced a certain buffer effect on the burst of cavitation bubbles, weaken the strength of ultrasonic cavitation effect [41]. In the work of Zhong and Xiong [23], they found changes in secondary structure of MPI were minimal at 30 and $50{ }^{\circ} \mathrm{C}$ but were significant at $70^{\circ} \mathrm{C}$. Furthermore, the dissociation of native components followed by reaggregation into soluble particles following ultrasound treatment at $70{ }^{\circ} \mathrm{C}$ resulted in remarkable improvements of protein solubility, clarity, and stability of the mung protein isolate suspensions. However, Ashraf et al. [42] compared the effect of thermo-sonication pretreatment on mung bean under various temperature. FTIR analysis revealed that marked spectral changes were noted after ultrasound treatment at $20^{\circ} \mathrm{C}$ rather than at higher temperature. This difference was primarily due to the composition and solid content of the solution. As demonstrated in Figure 9, the correlation heat map showed that a huger number of dark areas was observed under $20^{\circ} \mathrm{C}$ temperature-controlled US in comparison to those of at $50^{\circ} \mathrm{C}$ and uncontrolled temperature, implying a closer connection among different indexes. In our experiment, the impact of cavitation effect at $20^{\circ} \mathrm{C}$ was more intensive than that of compared to $50{ }^{\circ} \mathrm{C}$.
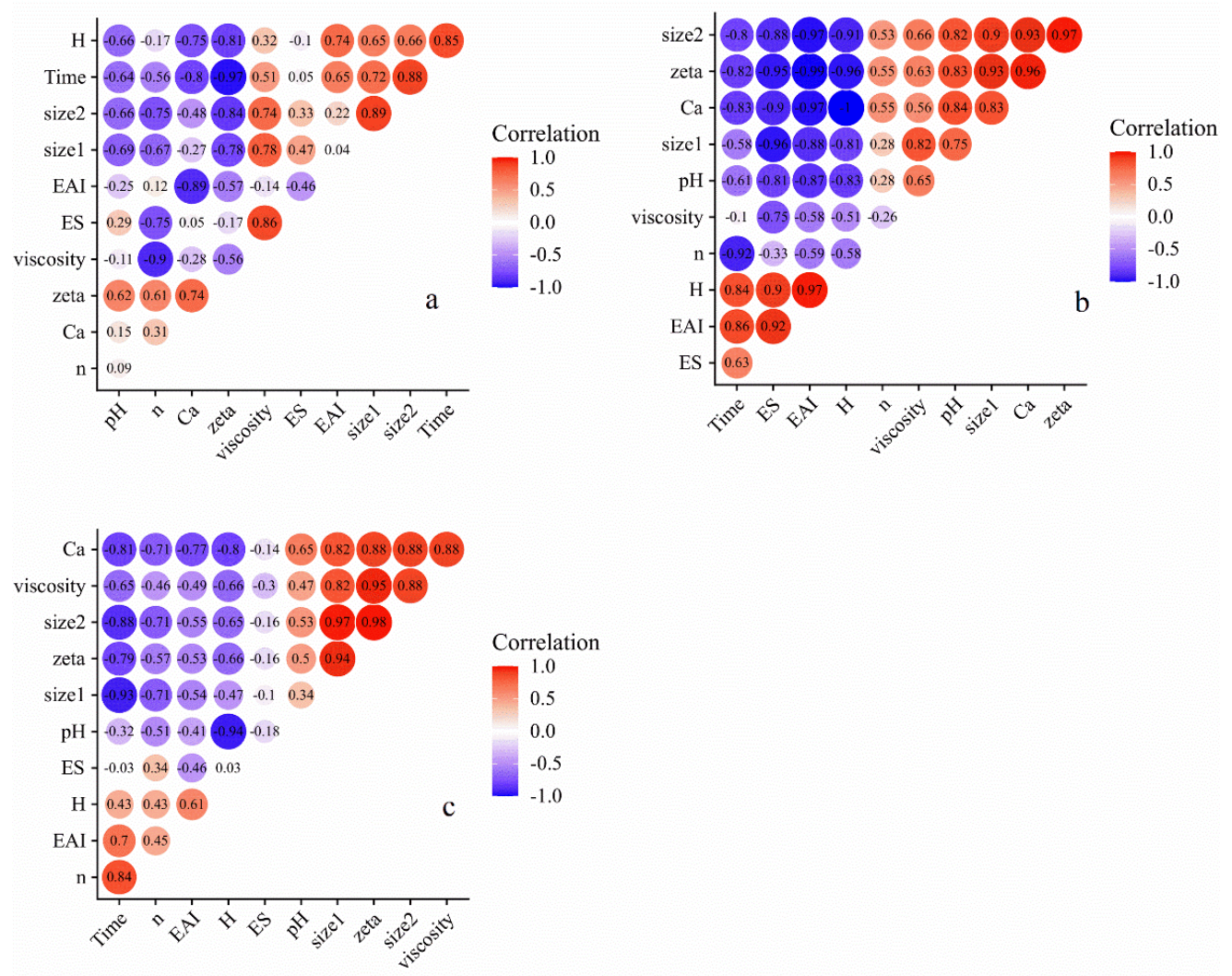

Figure 9. Correlation coefficient among different indexes of MCC samples treated by US at uncontrolled temperature (a), $20^{\circ} \mathrm{C}(\mathbf{b})$ and $50{ }^{\circ} \mathrm{C}$ (c). Size1: Overall particle size. Size2: Supernatant particle size. Ca: Ratio of micellar calcium content to soluble calcium content. H: Surface hydrophobicity. n: Flow behavior index. EAI: Emulsion activity index. ES: Emulsion stability. Zeta: Zeta-potential.

\section{Conclusions}

The effect of temperature-controlled ultrasound on the physical and functional properties of micellar casein concentrate were studied on a pilot scale. The present study showed that $20{ }^{\circ} \mathrm{C}$ US treatment $(20 \mathrm{kHz}, 453 \mathrm{~W}$ and $50 \%$ amplitude) for $30 \mathrm{~min}$ significantly improved emulsifying activity index. This could help expand the application of MCC in food industry.

Although US could slightly dissociate casein micelles, aggregates could be formed after long-time US treatment, whether at or without temperature control. The former was mainly caused by hydrophobic interaction, while the latter was primarily attributed to the 
denatured serum protein. Prolonged US time resulted in the change of fluid state, causing it to display shear thickening behavior, indicating the unstable state of the solution system. Therefore, long-time (60 $\mathrm{min})$ ultrasound should be avoided in industrial applications, because the unstable state of US treated samples would affect its subsequent processability and the final quality of the product.

Temperature control was crucial for the ultrasound effect on MCC solutions. Compared with $50{ }^{\circ} \mathrm{C}$ temperature-controlled sonication, $20^{\circ} \mathrm{C}$ had a stronger influence on particle size, viscosity and hydrophobicity, which might imply a stronger cavitation effect.

Therefore, US treatment with temperature control can be used to improve MCC functional properties and make the modified protein as a potential ingredient in different food applications including cheese, cake and ice cream. However, further research on the application in the real food system is still necessary, and this is one of our next plans.

Author Contributions: Conceptualization, B.S.; methodology, B.S.; investigation, B.S. and N.X.; formal analysis, Y.Z. and B.Y.; software, Y.Z. and P.Z.; writing-review \& editing, X.P.; supervision, S.Z. and J.L.; Project administration, J.L. All authors have read and agreed to the published version of the manuscript.

Funding: This work was supported by the National Key R\&D Program of China (2017YFE0131800, 2018YFC1604301), Ningxia Key R\&D Program (2021BEF02022), Inner Mongolia Science and Technology Program (2021GG0368).

Institutional Review Board Statement: Not applicable.

Informed Consent Statement: Not applicable.

Data Availability Statement: The data presented in this study are available on request from the corresponding authors.

Conflicts of Interest: The authors declare that there are no relevant financial or non-financial competing interests to report.

\section{References}

1. Nomura, H.; Koda, S. Chapter 1-What Is Sonochemistry? In Sonochemistry and the Acoustic Bubble; Grieser, F., Choi, P.-K., Enomoto, N., Harada, H., Okitsu, K., Yasui, K., Eds.; Elsevier: Amsterdam, The Netherlands, 2015; pp. 1-9. [CrossRef]

2. Ashokkumar, M. Applications of ultrasound in food and bioprocessing. Ultrason. Sonochem. 2015, 25, 17-23. [CrossRef]

3. Soltani Firouz, M. 6-Application of high-intensity ultrasound in food processing for improvement of food quality. In Design and Optimization of Innovative Food Processing Techniques Assisted by Ultrasound; Barba, F.J., Cravotto, G., Chemat, F., Rodriguez, J.M.L., Munekata, P.E.S., Eds.; Academic Press: Cambridge, MA, USA, 2021; pp. 143-167. [CrossRef]

4. Silva, M.; Zisu, B.; Chandrapala, J. Influence of low-frequency ultrasound on the physico-chemical and structural characteristics of milk systems with varying casein to whey protein ratios. Ultrason. Sonochem. 2018, 49, 268-276. [CrossRef]

5. Wang, D.; Hou, F.; Ma, X.; Chen, W.; Yan, L.; Ding, T.; Ye, X.; Liu, D. Study on the mechanism of ultrasound-accelerated enzymatic hydrolysis of starch: Analysis of ultrasound effect on different objects. Int. J. Biol. Macromol. 2021, 148, 493-500. [CrossRef] [PubMed]

6. Soares, A.D.S.; Leite Júnior, B.R.D.C.; Tribst, A.A.L.; Augusto, P.E.D.; Ramos, A.M. Effect of ultrasound on goat cream hydrolysis by lipase: Evaluation on enzyme, substrate and assisted reaction. LWT 2020, 130, 109636. [CrossRef]

7. Carter, B.G.; Cheng, N.; Kapoor, R.; Meletharayil, G.H.; Drake, M.A. Invited review: Microfiltration-derived casein and whey proteins from milk. J. Dairy Sci. 2021, 104, 2465-2479. [CrossRef] [PubMed]

8. Bong, D.D.; Moraru, C.I. Use of micellar casein concentrate for Greek-style yogurt manufacturing: Effects on processing and product properties. J. Dairy Sci. 2014, 97, 1259-1269. [CrossRef]

9. Hammam, A.; Martínez-Monteagudo, S.; Metzger, L.E. Progress in micellar casein concentrate: Production and applications. Compr. Rev. Food Sci. Food Saf. 2021, 74, 1-24. [CrossRef]

10. Hurt, E.; Barbano, D.M. Processing factors that influence casein and serum protein separation by microfiltration1. J. Dairy Sci. 2010, 93, 4928-4941. [CrossRef]

11. Zhang, R.; Pang, X.; Lu, J.; Liu, L.; Zhang, S.; Lv, J. Effect of high intensity ultrasound pretreatment on functional and structural properties of micellar casein concentrates. Ultrason. Sonochem. 2018, 47, 10-16. [CrossRef] [PubMed]

12. Yang, M.; Zeng, Q.; Wang, Y.; Qin, J.; Zheng, J.; Wa, W. Effect of ultrasound pretreatment on the physicochemical properties and simulated gastrointestinal digestibility of micellar casein concentrates. LWT 2021, 136, 110319. [CrossRef] 
13. Pinto, C.A.; Lima, V.J.; Amaral, R.A.; Pateiro, M.; Lorenzo, J.M.; Saraiva, J.A. 10—Development of fermented food products assisted by ultrasound. In Design and Optimization of Innovative Food Processing Techniques Assisted by Ultrasound; Barba, F.J., Cravotto, G., Chemat, F., Rodriguez, J.M.L., Munekata, P.E.S., Eds.; Academic Press: Cambridge, MA, USA, 2021 ; pp. $275-298$. [CrossRef]

14. Zhang, S.; Chen, J.; Pang, X.; Lu, J.; Yue, M.; Liu, L.; Lv, J. Pilot scale production of micellar casein concentrate using stainless steel membrane. Int. Dairy J. 2018, 80, 26-34. [CrossRef]

15. Yang, B.; Zhang, S.; Pang, X.; Lu, J.; Wu, Z.; Yue, Y.; Wang, T.; Jiang, Z.; Lv, J. Separation of serum proteins and micellar casein from skim goat milk by pilot-scale $0.05-\mu \mathrm{m}$ pore-sized ceramic membrane at $50{ }^{\circ} \mathrm{C}$. J. Food Process Eng. 2019, 43. [CrossRef]

16. Song, B.; Zhang, Y.; Lu, J.; Pang, X.; Wei, M.; Zheng, S.; Zhang, M.; Zhang, S.; Lv, J. Effect of different diafiltration process on the protein fractionation of skim milk by cross flow microfiltration. LWT 2021, 152, 112330. [CrossRef]

17. McCarthy, N.A.; Kelly, P.M.; Maher, P.G.; Fenelon, M.A. Dissolution of milk protein concentrate (MPC) powders by ultrasonication. J. Food Eng. 2014, 126, 142-148. [CrossRef]

18. Nazari, B.; Mohammadifar, M.A.; Shojaee-Aliabadi, S.; Feizollahi, E.; Mirmoghtadaie, L. Effect of ultrasound treatments on functional properties and structure of millet protein concentrate. Ultrason. Sonochem. 2018, 41, 382-388. [CrossRef]

19. Rostami, B.; Morini, G.L. Experimental characterization of a micro cross-junction as generator of Newtonian and non-Newtonian droplets in silicone oil flow at low Capillary numbers. Exp. Therm. Fluid Sci. 2019, 103, 191-200. [CrossRef]

20. Nassar, K.S.; Lu, J.; Pang, X.; Ragab, E.S.; Yue, Y.; Obaroakpo, U.J.; Gebreyowhans, S.; Hussain, N.; Bayou, Y.; Zhang, S.; et al. The functionality of micellar casein produced from retentate caprine milk treated by HP. J. Food Eng. 2021, 288, 110144. [CrossRef]

21. Yanjun, S.; Jianhang, C.; Shuwen, Z.; Hongjuan, L.; Jing, L.; Lu, L.; Uluko, H.; Yanling, S.; Wenming, C.; Wupeng, G.; et al. Effect of power ultrasound pre-treatment on the physical and functional properties of reconstituted milk protein concentrate. J. Food Eng. 2014, 124, 11-18. [CrossRef]

22. Fan, Y.; Peng, G.; Pang, X.; Wen, Z.; Yi, J. Physicochemical, emulsifying, and interfacial properties of different whey protein aggregates obtained by thermal treatment. LWT 2021, 149, 111904. [CrossRef]

23. Zhong, Z.; Xiong, Y.L. Thermosonication-induced structural changes and solution properties of mung bean protein. Ultrason. Sonochem. 2020, 62, 104908. [CrossRef]

24. Chen, L.; Ettelaie, R.; Akhtar, M. Improved enzymatic accessibility of peanut protein isolate pre-treated using thermosonication. Food Hydrocoll. 2019, 93, 308-316. [CrossRef]

25. Shanmugam, A.; Chandrapala, J.; Ashokkumar, M. The effect of ultrasound on the physical and functional properties of skim milk. Innov. Food Sci. Emerg. Technol. 2012, 16, 251-258. [CrossRef]

26. Chandrapala, J.; Martin, G.J.O.; Zisu, B.; Kentish, S.E.; Ashokkumar, M. The effect of ultrasound on casein micelle integrity. J. Dairy Sci. 2012, 95, 6882-6890. [CrossRef]

27. Nguyen, N.H.A.; Anema, S.G. Effect of ultrasonication on the properties of skim milk used in the formation of acid gels. Innov. Food Sci. Emerg. Technol. 2010, 11, 616-622. [CrossRef]

28. Reitmaier, M.; Barbosa, B.; Sigler, S.; Heidebrecht, H.-J.; Kulozik, U. Impact of different aqueous phases on casein micelles: Kinetics of physicochemical changes under variation of water hardness and diafiltration conditions. Int. Dairy J. 2020, 109, 104776. [CrossRef]

29. Supeno Kruus, P. Sonochemical formation of nitrate and nitrite in water. Ultrason. Sonochem. 2000, 7, 109-113. [CrossRef]

30. Liu, Z.; Juliano, P.; Williams, R.P.W.; Niere, J.; Augustin, M.A. Ultrasound improves the renneting properties of milk. Ultrason. Sonochem. 2014, 21, 2131-2137. [CrossRef]

31. Hong Bui, A.T.; Cozzolino, D.; Zisu, B.; Chandrapala, J. Infrared analysis of ultrasound treated milk systems with different levels of caseins, whey proteins and fat. Int. Dairy J. 2021, 117, 104983. [CrossRef]

32. Deshpande, V.K.; Walsh, M.K. Effect of sonication on the viscosity of reconstituted skim milk powder and milk protein concentrate as influenced by solids concentration, temperature and sonication. Int. Dairy J. 2018, 78, 122-129. [CrossRef]

33. Lo, B.; Gorczyca, E.; Kasapis, S.; Zisu, B. Effect of low-frequency ultrasound on the particle size, solubility and surface charge of reconstituted sodium caseinate. Ultrason. Sonochem. 2019, 58, 104525. [CrossRef]

34. Tong, X.; Cao, J.; Tian, T.; Lyu, B.; Miao, L.; Lian, Z.; Cui, W.; Liu, S.; Wang, H.; Jiang, L. Changes in structure, rheological property and antioxidant activity of soy protein isolate fibrils by ultrasound pretreatment and EGCG. Food Hydrocoll. 2022, 122, 107084. [CrossRef]

35. Dörner, P.; Schröder, W.; Klaas, M. Experimental quantification of oscillating flow in finite-length straight elastic vessels for Newtonian and non-Newtonian fluids. Eur. J. Mech.—B/Fluids 2021, 87, 180-195. [CrossRef]

36. Dukhin, A.; Parlia, S.; Somasundaran, P. Rheology of non-Newtonian liquid mixtures and the role of molecular chain length. $J$. Colloid Interface Sci. 2020, 560, 492-501. [CrossRef] [PubMed]

37. Martínez-Sanz, M.; Garrido-Fernández, A.; Mijlkovic, A.; Krona, A.; Martínez-Abad, A.; Coll-Marqués, J.M.; López-Rubio, A.; Lopez-Sanchez, P. Composition and rheological properties of microalgae suspensions: Impact of ultrasound processing. Algal Res. 2020, 49, 101960. [CrossRef]

38. Raikos, V. Effect of heat treatment on milk protein functionality at emulsion interfaces. A review. Food Hydrocoll. 2010, 24, 259-265. [CrossRef]

39. Xiong, T.; Ye, X.; Su, Y.; Chen, X.; Sun, H.; Li, B.; Chen, Y. Identification and quantification of proteins at adsorption layer of emulsion stabilized by pea protein isolates. Colloids Surf. B Biointerfaces 2018, 171, 1-9. [CrossRef] 
40. Andrews, D.R. Ultrasonics and Acoustics. In Encyclopedia of Physical Science and Technology, 3rd ed.; Meyers, R.A., Ed.; Academic Press: New York, NY, USA, 2003; pp. 269-287. [CrossRef]

41. Holmes, M.J.; Povey, M.J.W. Ultrasonic Particle Sizing in Emulsions. Ultrasound Food Process. 2017, 27-64. [CrossRef]

42. Ashraf, J.; Liu, L.; Awais, M.; Xiao, T.; Wang, L.; Zhou, X.; Tong, L.-T.; Zhou, S. Effect of thermosonication pre-treatment on mung bean (Vigna radiata) and white kidney bean (Phaseolus vulgaris) proteins: Enzymatic hydrolysis, cholesterol lowering activity and structural characterization. Ultrason. Sonochem. 2020, 66, 105121. [CrossRef] 